\title{
Gynura procumbens Ethanolic Extract Promotes Lymphocyte Activation and Regulatory T Cell Generation In Vitro
}

Dinia Rizqi Dwijayanti ${ }^{1}$, Muhaimin Rifa' ${ }^{1}{ }^{1}$

${ }^{1}$ Department of Biology, Facullty of Mathematic and Natural Sciences, University of Brawijaya, Malang, Indonesia

\section{ABSTRACT}

Immune system is a system of biological structures and processes within organism directed to protect against invaded pathogen. Cellular and humoral immune system mediated by immunocompetent cells such as $\mathrm{CD}^{+} \mathrm{T}$ cells, $\mathrm{CD}^{+} \mathrm{T}$ cells, CD4 ${ }^{+} \mathrm{CD} 25^{+} \mathrm{T}$ cells, and B220 cells play important role for maintaining immunological surveillance. The purpose of this study was to determine the effect of ethanolic extract of G. procumbens leaves (EEGL) on the profile of $\mathrm{CD} 4^{+} \mathrm{T}$ cells, $\mathrm{CD} 4^{+} \mathrm{CD} 25^{+} \mathrm{T}$ cells, and $\mathrm{B} 220^{+}$cells. Splenic cells were isolated from $\mathrm{BALB} / \mathrm{c}$ mice and cultured in RPMI1640 medium in the presence of EEGL. After 4 days of incubation, cells were harvested, stained with antibodies and analyzed by flow cytometer. The data were analyzed by one-way ANOVA with $\alpha=0.05$ and Tukey test using SPSS 16.0 for windows. The results showed that the extract of $G$. procumbens could increase proliferation of $\mathrm{CD} 4^{+} \mathrm{CD} 62 \mathrm{~L}^{-} \mathrm{T}$ cell, $\mathrm{CD} 4^{+} \mathrm{CD} 25^{+} \mathrm{T}$ cells, and $\mathrm{B} 220^{+}$cells compared to the control. Here, we showed the biological effect of $G$. procumbens as medicinal herb with immunomodulatory activity and the dose of $0.1 \mu \mathrm{g} / \mathrm{ml}$ and $1.0 \mu \mathrm{g} / \mathrm{ml}$ could promote $\mathrm{T}$ cell activation compared to the highest dose of $10 \mu \mathrm{g} / \mathrm{ml}$. Interestingly, the dose of $10 \mu \mathrm{g} / \mathrm{ml}$ rather promote than inhibit B cell proliferation.

Keywords: $B 220^{+}, C D 4^{+}, C D 4^{+} C D 25^{+}$, Gynura procumbens, proliferation

\section{INTRODUCTION}

Immune system is a defense system which protects the body from pathogen. It consists of cellular and humoral immune system. Cellular immune system is the immune system mediated by $\mathrm{T}$ cells either $\mathrm{T}$ helper cells $\left(\mathrm{CD}^{+}\right)$or cytotoxic $\mathrm{T}$ cells $\left(\mathrm{CD}^{+}\right)$. Besides, the cellular immune system cells also contain the regulatory $\mathrm{T}$ cells $\mathrm{CD} 4^{+} \mathrm{CD} 25^{+}$cells which have a function to control the performance of $\mathrm{CD}^{+}$and $\mathrm{CD}^{+} \mathrm{T}^{+y m p h o-}$ cytes. Humoral immune system is the immune system involving activation of $\mathrm{B}$ cells $\left(\mathrm{B} 220^{+}\right)$and antibody production. Immune system can be activated by the presence of foreign antigens as well as by the induction of immunomodulatory compounds $[1,2]$.

G. procumbens is native plant from China, Myanmar and some Asian countries such as Indonesia, Malaysia, and Thailand. In Indonesia it is widely grown in Java, Sumatra, and Bali [3]. Based on the results of previous studies, $G$. procumbens leaves have benefit to cure various kinds of diseases. It has been

\footnotetext{
*Corresponding author:
}

Muhaimin Rifa'i, Ph.D.

Department of Biology, Faculty of Mathematics and Natural

Sciences, University of Brawijaya, Malang 65145, Indonesia

Phone/Fax: 62-341-575841/62-341-575841, e-mail: rifa123@ub.ac.id known that the extract of $G$. procumbens containing anti-hyperglycemic cures diabetes mellitus by decreasing blood glucose level. G. procumbens has a hypoglycemic effect and its leaves extract has an anti-hyperlipidemia property [4-7]. Another benefit of its leaves was reported to cure inflammation of eyes, toothache, rheumatic, cysts, and tumors. Anticancer effect of $G$. procumbens plants is associated with high antioxidant content. In addition, some studies indicated that the ethanol extract of $G$. procumbens leaves is able to inhibit the process of angiogenesis [8-10]. G. procumbens is also known for its anti-angiogenesis agent with an ability to inhibit the formation of new blood vessels so that the distribution of food to cancer cells is inhibited. However, tumor progression is not only mediated by angiogenesis but also the over expression of mortalin molecules [11-15].

A qualitative analysis of $G$. procumbens by thinlayer chromatography had detected the presence of sterols, triterpenes, phenolic compounds, polyphenols, and essential oils in that medicinal plant. G. procumbens contains sterols, sterol glycosides, quercetin, kaempferol-3-O-neohesperidosida, kaempferol-3-glucoside, quercetin-3-ramnosil, galactoside, and quercetin3-O-ramnosil glucoside $[1-6,15,16]$. The results of 
study showed that the polar fraction of ethanol $G$. procumbens leaves has three classes of flavonoids: flavones, auron, and flavonols.16 Flavonoids contained in the ethanol extract of $G$. procumbens are immunomodulatory compound. An immunomodulatory compound has worked to increase or suppress the body's defense mechanisms, both specific and non-specific, as well as cellular and humoral defense mechanisms. Most immunomodulatory compounds enhance the immune system by increasing the proliferation of immunocompetent cells [17].

\section{MATERIALS AND METHODS}

\section{Culture Preparation}

In this experiment we used RPMI 1640 medium containing 10\% Fetal Bovine Serum (FBS), 1\% of antibiotics penicillin and streptomycin, $50 \mu \mathrm{M}$ of 2-mercaptoethanol, and $1.0 \% \alpha$-CD3 (supernatant). This medium was filtered with cell strainer (Millipore membrane). G. procumbens extract powder was $0.2 \mathrm{~g}$ and dissolved in $200 \mathrm{ml}$ of sterile water as a stock solution with $1 \mathrm{mg} / \mathrm{ml}$ concentration. $100 \mu \mathrm{l}$ of stock solution was diluted in $9900 \mu \mathrm{l}$ medium as a dose 1 medium with $10 \mu \mathrm{g} / \mathrm{ml}$ concentration. Dose 1 medium was also filtered with cell strainer and transferred to a new propylene tube. $500 \mu \mathrm{l}$ of dose 1 medium was diluted in $4500 \mu \mathrm{l}$ medium, to obtain dose 2 medium with 1 $\mu \mathrm{g} / \mathrm{ml}$ concentration. $500 \mu \mathrm{l}$ of dose 2 medium was diluted in of $4500 \mu \mathrm{l}$ medium, and it would be dose 3 medium with $0.1 \mu \mathrm{g} / \mathrm{ml}$ concentration.

\section{Cell Isolation and Calculation}

Spleen was isolated and washed in petri dish containing PBS, transferred to another petri dish which also contained PBS and then crushed. The suspension was transferred into a polypropylene tube and then centrifuged with a speed of $1500 \mathrm{rpm}$ for 5 minutes at $10^{\circ} \mathrm{C}$. Pellet was resuspended in $1 \mathrm{ml}$ of medium. Nucleated cells were calculated by taking $10 \mu \mathrm{l}$ of this suspension and added with $90 \mu \mathrm{l}$ Evans blue then the number of cells was counted with haemocytometer.

\section{Cell culture}

Splenic cells $\left(3 \times 10^{6}\right)$ were cultured in RPMI-1640 medium containing 10\% Fetal Bovine Serum (FBS), $1 \%$ penicillin and streptomycin, 2-mercaptoethanol 50 $\mu \mathrm{M}$, and $1 \% \alpha-\mathrm{CD} 3$ supernatant in 48 well plates. Cell cultures were incubated in $5 \%$ of $\mathrm{CO} 2$ at $37^{\circ} \mathrm{C}$ for 4 days. After 4 days, cells were harvested then centrifuged with a speed of $1500 \mathrm{rpm}$ for 5 minutes at $4^{\circ} \mathrm{C}$. Pellets were then subjected to cell surface molecule staining.

\section{Flow cytometry Analysis}

Antibodies used in the study were FITC-conjugated rat anti-mouse $\mathrm{CD} 4$, $\mathrm{PE}$-conjugated anti-mouse $\mathrm{CD} 25$ (clone PC61.5), PE/Cy5-conjugated anti-mouse CD62L (clone MEL-14), and PE/Cy5-conjugated anti-mouse B220. Samples were incubated in the ice box for 30 minutes. Each sample was added with $500 \mu \mathrm{l}$ PBS and transferred to the flow cytometry cuvettes. Samples were ready for running with flow cytometry.

\section{Data Analysis}

Flow cytometry results were visualized by $\mathrm{BD}$ CellQuest $\mathrm{PRO}^{\mathrm{TM}}$ software, tabulated, and analyzed by ANOVA analysis with a significance of $0.05 \%$ in SPSS version 16 for windows.

\section{Data analysis}

Data analysis was performed using SPSS 16 with Kruskal-Wallis test, Independent T-test, and Pearson correlation test with $\alpha<0.05$.

\section{RESULTS AND DISCUSSION}

G. procumbens extract had an ability to activate CD4 T cells indicated by the loss of CD62L molecule. G. procumbens leaves with $10 \mu \mathrm{g} / \mathrm{ml}$ concentration was able to increase a relative number of activated $\mathrm{T}$ cells significantly $(\mathrm{p}<0.05)$. At these concentrations, the relative number of $\mathrm{CD} 4{ }^{+} \mathrm{CD} 62 \mathrm{~L}^{+} \mathrm{T}$ cells was $61.90 \%$ and the relative number of $\mathrm{CD}^{+} \mathrm{CD} 62 \mathrm{~L}^{-} \mathrm{T}$ cells was $38.10 \%$. G. procumbens leaves ethanol extract in cell culture showed a significant increase $(\mathrm{p}>0.05)$ of $\mathrm{CD}^{+} \mathrm{CD} 25^{+}$regulatory $\mathrm{T}$ cells compared with controls (Figure 2). The relative number of $\mathrm{CD} 4^{+} \mathrm{CD} 25^{+} \mathrm{T}$ cells in control was $14.92 \%$, while relative number of cells in the dose 1 reached $18.66 \%$. G. procumbens leaves ethanol extract was able to increase the relative number of $\mathrm{B}_{220}{ }^{+}$cells from $10.96 \%$ in the control to be $26.97 \%$ in the dose 1 extract (Figure 3). Based on statistical tests with one-way ANOVA, the results differ significantly with $\mathrm{p}<0.05$. However, another case with $\mathrm{CD} 4^{+}$ $\mathrm{T}$ cells both $\mathrm{CD} 4{ }^{+} \mathrm{CD} 62 \mathrm{~L}^{-}$and $\mathrm{CD} 4{ }^{+} \mathrm{CD} 25^{+} \mathrm{T}$ cells, extract with dose 2 and dose 3 actually gave effect to the decrease of relative $\mathrm{B}_{2} 20^{+}$cell when compared to a control namely $8.27 \%$ and $7.79 \%$. The relative number of cells in the control was significantly different $(\mathrm{p}<0.05 \%)$ with dose 2 and 3 treatments, while between dose 2 and 3 did not differ significantly. The decrease in the relative number of $\mathrm{B}_{2} 20^{+}$cells at dose 2 and 3 compared to the control indicated that $G$. 


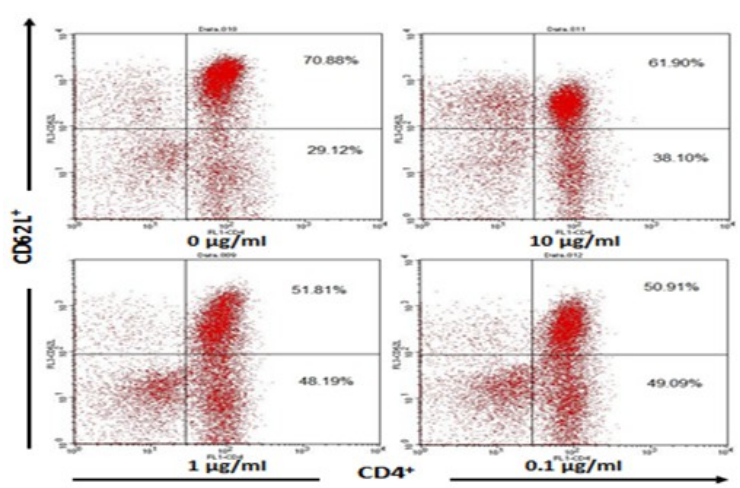

Figure 1. $T$ cell stimulation using ethanol extract of $G$. procumbens for four days increased the number of activated T cells. Spleen cells were cultured in RPMI medium for four days. The up left panel is control without G. procumbens ethanol extract addition. In the up right panel, cell culture was added with $10 \mu \mathrm{g} / \mathrm{ml}$ ethanol extract of $G$. procumbens. In low left panel, cell culture was added with $1 \mu \mathrm{g} / \mathrm{ml}$ ethanol extract of $G$. procumbens. Meanwhile, in low right panel cell culture was added with $0.1 \mu \mathrm{g} / \mathrm{ml}$ ethanol extract of $G$. procumbens. On day 4, cell culture was harvested and analyzed by flow cytometry. Naïve $\left(\mathrm{CD}_{4}^{+} \mathrm{CD} 62 \mathrm{~L}^{+}\right)$and activated $\left(\mathrm{CD} 4^{+} \mathrm{CD} 62 \mathrm{~L}^{-}\right) \mathrm{T}$ cells were presented in relative number. Data were mean $\pm \mathrm{SD}$ values of five mice in each group.

procumbens has role as immunostimulant, besides it may also act as an immunosuppressant. The immunosuppressant has opposite works with immunostimulant. Immunosuppressant tends to inhibit the transcription process of cytokines so that cytokines play role as the little cell activation levels [1].

CD62L are molecules mediating naive $\mathrm{T}$ cell migration to the peripheral lymphoid organs which are the site of initiation of the immune response [1]. In the control treatment, the relative number of naive CD4 T cells $\left(\mathrm{CD}^{+} \mathrm{CD}_{2} \mathrm{~L}^{+}\right)$was $70.88 \%$ and the relative number of $\mathrm{CD} 4 \mathrm{~T}$ cells that had been activated $\left(\mathrm{CD}^{+} \mathrm{CD}^{2} \mathrm{~L}^{-}\right)$was $29.12 \%$ (Figure 1 ). It showed that in the control treatment, CD4 T cells had not been activated. The administration of extract with $1 \mu \mathrm{g} / \mathrm{ml}$ and
$0.1 \mu \mathrm{g} / \mathrm{ml}$ concentrations showed higher cell activation significantly than that of control and treatment with a dose of $10 \mu \mathrm{g} / \mathrm{ml}(\mathrm{p}<0.05)$. The relative number of $\mathrm{CD}^{+} \mathrm{CD} 2 \mathrm{~L}^{+} \mathrm{T}$ cells at concentration of $1 \mu \mathrm{g} / \mathrm{ml}$ and $0.1 \mu \mathrm{g} / \mathrm{ml}$ extract were $51.81 \%$ and $50.91 \%$ respectively, whereas $\mathrm{CD}^{+} \mathrm{D} 62 \mathrm{~L}^{-} \mathrm{T}$ cells were $48.19 \%$ and $49.09 \%$ respectively. The extract dose of $1 \mu \mathrm{g} / \mathrm{ml}$ and $0.1 \mu \mathrm{g} / \mathrm{ml}$ to activate CD4 $\mathrm{T}$ cells showed no significant difference $(p>0.05)$. This data showed that the ethanol extract of $G$. procumbens leaves was able to increase the relative number of activated CD4 T cells. This increase provided evidence that $G$. procumbens has an ability as immunostimulant. Immunostimulatory compound is able to inhibit the activity of mitogen-Activated Protein Kinase (MAPK) [18]. MAPK is

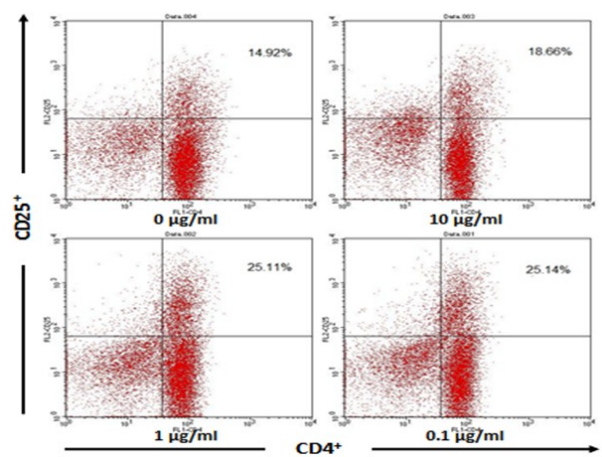

Figure 2. T cell stimulation using ethanol extract of G. procumbens for four days showed the increase of CD4 ${ }^{+} \mathrm{CD} 25^{+} \mathrm{T}$ cells. Spleen cells were cultured in RPMI medium for four days. The up left panel is control without addition of ethanol extract of $G$. procumbens. In the up right panel, cell culture was added with $10 \mu \mathrm{g} / \mathrm{ml}$ ethanol extract of $G$. procumbens, in low left panel cell culture was added with $1 \mu \mathrm{g} / \mathrm{ml}$ ethanol extract of $G$. procumbens, and in low right panel cell culture was added with $0.1 \mu \mathrm{g} / \mathrm{ml}$ ethanol extract of $G$. procumbens. On day 4, cell culture was harvested and analyzed by flow cytometry. $\mathrm{CD} 4{ }^{+} \mathrm{CD} 25^{+} \mathrm{T}$ cells were presented in relative number. Data were mean $\pm \mathrm{SD}$ values of five mice in each group. 


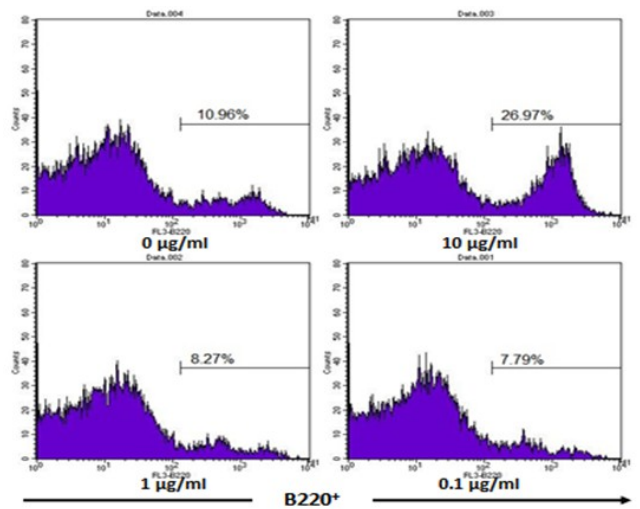

Figure 2. Culture cell stimulation using ethanol extract of $G$. procumbens for four days showed the increase of B220 $0^{+}$cells. Spleen cells were cultured in RPMI medium for four days. In the in up left panel, cell culture was without ethanol extract of $G$. procumbens. In up right panel cell culture was added with $10 \mu \mathrm{g} / \mathrm{ml}$ ethanol extract of $G$. procumbens, in low left panel cell culture was added with $1 \mu \mathrm{g} / \mathrm{ml}$ ethanol extract of $G$. procumbens, and in low right panel cell culture was added with $0.1 \mu \mathrm{g} / \mathrm{ml}$ ethanol extract of $G$. procumbens. On day 4, cell culture was harvested and analyzed by using flow cytometry. $\mathrm{B} 220^{+}$cells were presented in relative number. Data were mean $\pm \mathrm{SD}$ values of five mice in each group.

also known to play role in the activation of immunocompetent cells because it can induce the increase of cytokines IL-2. Exposure to IL-2 on the cell will cause cyclin D2 and cyclin E concentration increase, and serves to activate cyclin-dependent kinases (cdk) [19]. IL-2 is also capable to reduce the concentration of p27 protein that plays role in the inhibition of cdk activity. If the active cdk and p27 are inhibited then the cells will be induced to resume cell cycle from G1 to $\mathrm{S}$ phase and the cells will proliferate [20].

Regulatory $\mathrm{T}$ cells are $\mathrm{CD}^{+} \mathrm{T}$ cell population which express CD25 molecule, CD $4{ }^{+} \mathrm{CD} 25^{+}$. CD25 molecule is the alpha chain of the IL-2 receptor (IL2$\mathrm{R} \alpha$ ) [21-22]. The treatments of dose 2 and dose 3 resulted in increasing the relative number of cells namely $25.11 \%$ and $25.14 \%$, respectively. These numbers had significant differences $(\mathrm{p}<0.05)$ compared to control and dose 1 namely $14.92 \%$ and $18.66 \%$, respectively. The changes of $\mathrm{CD} 4^{+} \mathrm{CD} 25^{-} \mathrm{T}$ cells into $\mathrm{CD} 4^{+} \mathrm{CD} 25^{+}$could occur when $\mathrm{CD} 4 \mathrm{~T}$ cells were activated by stimuli such as immunomodulator substances. An increase in the number of $\mathrm{CD} 4^{+} \mathrm{CD} 25^{+} \mathrm{T}$ cells related to the increase of IL-2 production resulted by the $G$. procumbens stimulation. In addition to the direct stimulus of $G$. procumbens extract, $\mathrm{CD}^{+} \mathrm{T}$ cells which have been activated will also secrete IL-2 as a growth factor for both itself and other cells, one of which is a $\mathrm{CD}^{+} \mathrm{CD} 25^{+} \mathrm{T}$ cell.1 The increasing number of $\mathrm{CD} 4{ }^{+} \mathrm{CD} 25^{+} \mathrm{T}$ cells is also related to the role of $\mathrm{CD}^{+} \mathrm{CD} 25^{+} \mathrm{T}$ cells in the regulatory mechanism to balance the number of $\mathrm{CD} 4{ }^{+} \mathrm{CD} 62 \mathrm{~L}^{-} \mathrm{T}$ cells, $\mathrm{CD} 4^{+} \mathrm{T}$ cells that have been activated. According to Rifa'i et al.,
$\mathrm{CD} 4^{+} \mathrm{CD} 25^{+} \mathrm{T}$ cells have important role in the immune system to create tolerant and maintain normal homeostasis. $\mathrm{CD}^{+} \mathrm{CD} 25^{+} \mathrm{T}$ cells are able to control effector cell functions that have been activated [23-24]. This ability is necessary to avoid the presence of autoreactivity effector cells.

The activation of B lymphocytes $\left(\mathrm{B} 220^{+}\right)$and antibody production include in humoral immune response to protect the extracellular area [1]. Activation of $\mathrm{B} 220^{+}$ cell is also one of the most important parts in the body defense mechanism. The increase in relative number

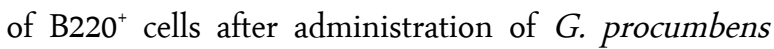
extract was closely associated with the increase of MAPK and IL-2 production. Craxton et al. further explained that MAPK also has a function to activate $\mathrm{Nu}$ clear Factor Kappa $\beta$ (NF-k $\beta$ ). NF-k $\beta$ is a transcription factor which stimulates $\mathrm{B} 220^{+}$cells to proliferate and differentiate [25]. Under these conditions, the $G$. procumbens leave's ethanolic extract may become an immunostimulator as well as immunosuppresant. According to Schroeter et al., the action of compound is very complex, sometimes synergistic and antagonistic; in the other time it depends on the specific components used, cell type, concentration, and experimental design. The statement proved that the difference in cell types respond differently to the same exposure of compound with the same concentration. In particular, this is the case in dose 2 and 3 whose effect is the increase in the relative number of $\mathrm{T}$ cells $\mathrm{CD} 4^{+} \mathrm{CD} 62 \mathrm{~L}^{-} \mathrm{T}$ cells and $\mathrm{CD} 4^{+} \mathrm{CD} 25^{+}$, but it gives the effect of decrease in the relative number of $\mathrm{B} 220^{+}$cells [26]. 


\section{CONCLUSIONS}

Based on the results and discussion, it can be concluded that the extract of G. procumbens may increase proliferation of $\mathrm{CD} 4{ }^{+} \mathrm{CD} 62 \mathrm{~L}-\mathrm{T}$ cell, $\mathrm{T}$ $\mathrm{CD} 4{ }^{+} \mathrm{CD} 25^{+}$, and $\mathrm{B} 220^{+}$compared to the control. 1 $\mu \mathrm{g} / \mathrm{ml}$ and $0.1 \mu \mathrm{g} / \mathrm{ml}$ doses showed the highest ability of $\mathrm{T}$ cell activation compared to $10 \mu \mathrm{g} / \mathrm{ml}$ dose, but it gives a suppressant effect on B cells. $10 \mu \mathrm{g} / \mathrm{ml}$ dose has the highest ability for $\mathrm{B}$ cell activation compared to the $1 \mu \mathrm{g} / \mathrm{ml}$ and $0.1 \mu \mathrm{g} / \mathrm{ml}$ doses.

\section{ACKNOWLEDGMENT}

The authors would like to thank University of Brawijaya Malang, Indonesia for providing study necessities, and Indonesian Ministry of Higher Education for supporting the financial under the Competitive Research Grant Scheme. Authors also want to thank Indriya R, S.Si., Dewi S., S.Si., M.Si., Ahmad Sony, S.Si., M.Si., and Bambang P., S.Si., for their support in conducting this experiment.

\section{REFERENCES}

1. Rifa'i M (2013) $\mathrm{CD} 4^{+} \mathrm{CD} 25^{+}$Regulatory $\mathrm{T}$ Cells Prevent Detrimental Autoimmune Reactions. Int J. The Open Autoimmunity Journal. Bentham Open Publisher. 5: 1-5.

2. Murphy K, Travers P, Walport M (2008) Immunobiology. 7th edition. Garland Science, Taylor \& Francis Group, LLC. USA.

3. Backer CA, Brink VD (1965) Flora of Java (Spermatophytes Only). Noordhoff-Groningen. Netherlands.

4. Akowuah GA, Amirin S, Mariam, Aminah A (2001) Blood sugar lowering activity of Gynura procumbens leaves extracts. Journal of Tropical Medicinal Plants. 2: 510.

5. Akowuah GA, Sadikun A, Mariam A (2002) Flavonoid identification and hypo-glycaemic studies of butanol fraction from Gynura procumbens. Pharmaceutical Biology. 40: 405-410.

6. Hassan Z, Yam MF, Ahmad M, Yusof APM (2010) Antidiabetic Properties and Mechanism of Action of Gynura procumbens Water Extract in Streptozotocin-Induced Diabetic Rats. Molecules. 15: 9008-9023.

7. Zhang XF and Tan BK (2000) Effects of an Ethanolic Extract of Gynura procumbens Serum Glucose, Cholesterol and Triglyceride Levels in Normal and StreptozotocinInduced Diabetic Rats. Singapore Medical Journal. 41: 913.

8. Dalimartha S (2001) Indonesian Medicinal Plants. 1st edition. Trubus Agriwidia. Jakarta.

9. Poh TF, Ng HK, Hoe SZ, Lam SK (2013) Gynura procumbens Causes Vasodilation by Inhibiting An- giotensin II and Enhancing Bradykinin Actions. J Cardiovasc Pharmacol. doi:10.1097/FJC.0b013e31828685b3.

10. Hew C Sen, Khoo BY, Gam LH (2013) The Anti-Cancer Property of Proteins Extracted from Gynura procumbens (Lour.) Merr. PLoS One. 8:doi:10.1371/journal.pone. 0068524.

11. Seow LJ, Beh HK, Majid AMSA, Murugaiyah V, Ismail N, Asmawi MZ (2011) Anti-angiogenic activity of Gynura segetum leaf extracts and its fractions. J Ethnopharmacol. 134:221-7. doi:10.1016/j.jep.2010.12.007.

12. Wang H, Zhou JW, Fu DH, Zhou Y, Cheng WZ, Liu ZL (2013) Gynura procumbens ethanolic extract suppresses osteosarcoma cell proliferation and metastasis in vitro. Oncol Lett. 6:113-7. doi:10.3892/ol.2013.1315.

13. Puangpronpitag D, Chaichanadee S, Naowaratwattana W, Sittiwet C, Thammasarn K, et al. (2010) Evaluation of nutritional value and antioxidative properties of the medicinal plant Gynura procumbens extract. Asian Journal of Plant Sciences. 9: 146-151.

14. Jenie RI and Meiyanto E (2008) Combination of Sambung Nyawa (Gynura procumbens) Leaves Ethyl Acetate Fraction-Doxorubicin Induces Apoptosis in Human Breast Cancer T47D cells. Gajah Mada University, Yogyakarta.

15. 15. Utomo DH, Widodo N, Rifa'i M (2012) Identifications small molecules inhibitor of p53-mortalin complex for cancer drug using virtual screening. Bioinformation. 8(9):426-429

16. Hew CS, Gam LH (2011) Proteome analysis of abundant proteins extracted from the leaf of Gynura procumbens (Lour.) Merr. Applied Biochemistry and Biotechnology. 165: 1577-1586.

17. Rachmut IH, Samuels N, Melnick SJ, Ramachandran C, Sharabi Y, Pavlovsky A, et al. (2013) Immunomodulatory effects of the botanical compound LCS101: implications for cancer treatment. Onco Targets Ther. 6: 437-45. doi: 10.2147/OTT.S42038.

18. Middleton E, Kandaswami C, and Theoharides TC (2000) The Effects of Plant Flavonoids on Mammalian Cells: Implications for Inflammation, Heart Disease, and Cancer. Journal Pharmacol. 52(4): 673-751.

19. Nworu CS, Akah PA, Okoye FBC, Proksch P, and Esimone CO (2010) The Effects of Phyllanthus niruri Aqueus Ectract on the Activation of Murine Lymphocytes and Bone Marrow-Derived Macrophages. Immunological Investigations Informa Healthcare. 39: 245-267.

20. Fathir A, Rifa'i M, Widodo (2014) Activity Of Aqueous Leaf Extract Of Horseradish Tree On Helper T-Cell And Cytotoxic T- Cell In Mice Infected With Salmonella Thypi. Veteriner J. 15 (1): 144-122.

21. Rifai'i M (2010) Andrographolide ameliorate rheumatoid arthritis by promoting the development of regulatory $\mathrm{T}$ 
cells. Journal of Tropical Life Science. 1(1): 5-8.

22. Lee $\mathrm{YH}$ and Rifa'i M (2011) $\mathrm{CD} 4^{+} \mathrm{CD} 25^{+} \mathrm{FOXP} 3^{+}$Regulatory $\mathrm{T}$ Cells In Allogeneic Hematopoietic Cell Transplantation. Journal of Tropical Life Science. 1(2): 69-75.

23. Rifa'i M, Shi Z, Zhang SY, Lee YH, Shiku H, Isobe K, Suzuki $\mathrm{H}$ (2008) $\mathrm{CD}^{+} \mathrm{CD} 122^{+}$regulatory $\mathrm{T}$ cells recognize activated $\mathrm{T}$ cells via conventional MHC class I$\alpha \beta T C R$ interaction and become IL-10-producing active regulatory cells. Int Immunology. 20(7): 937-947.

24. Rifa'i M, Widodo N (2014) Significance of propolis administration for homeostasis of $\mathrm{CD} 4^{+} \mathrm{CD} 25^{+}$immunoregu- latory $\mathrm{T}$ cells controlling hyperglycemia. SpringerPlus. 3 (1): $1-8$

25. Craxton A, Shu G, Graves JD, Saklatvala J, Krebs EG, and Clark EA (1998) P38 MAPK is Required for CD40-Induced Gene Wxpression and Proliferatio in B Lymphocytes. Journal of Immunology.161: 3225-3236.

26. Schroeter H, Boyd C, Spencer JPE, Williams RJ, Cadenas E, and Rice-Evans C (2002) MAPK Signaling in Neuro Degeneration: Influences of Flavonoids and of Nitric Oxide. Neurobiology of Aging. 23: 861-880. 